\title{
7. LOWER CRETACEOUS AMMONOIDEA FROM THE NORTHERN ATLANTIC, LEG 47B, HOLE 398D, DSDP
}

Otto Renz, Museum of Natural History, Basel, Switzerland

\section{INTRODUCTION}

Hole 398D ( $\left.40^{\circ} 57.6^{\prime} \mathrm{N}, 10^{\circ} 43.1^{\prime} \mathrm{W}\right)$ is under about 3900 meters of water, 90 kilometers from the western coast of the Iberian Peninsula and south of Vigo Seamount. Drilling penetrated the Paleocene-Cretaceous boundary at a subbottom depth of 800 meters and terminated at 1740 meters in Hauterivian limestone.

The Lower Cretaceous consists predominantly of a 720meter body of uniform, dark gray claystones with thin turbidite interbeds. These claystones yielded 21 ammonites, 2 Lamellaptychi, 1 small gastropod, a fragment of Inoceramus, and some pieces of unidentified belemnites.

The ammonites are distinguishable into two assemblages: Albian and Barremian. The younger Albian congregation of ammonites ranges from about 1110 to 1365 meters in Cores 72 to 99 (Figure 1). This assemblage includes the upper Albian (although not proven on the basis of ammonite distribution), a recognizable middle Albian, and the mammillatum Zone of the lower Albian. Ammonites are not present that would indicate a tardefurcata Zone in the lowermost Albian. The older Barremian assemblage consists of only three ammonites collected between 1636 and 1663 meters in Cores 127 to 130 .

A Lamellaptychus angulocostatus (Peters), recovered from 1720 meters in Core 136, indicates Hauterivian deposits.

\section{ALBIAN}

The ammonite fauna of the Albian consists of 18 specimens that represent 11 identifiable species and subspecies of the Families Phylloceratidae, Desmoceratidae, Douvilliceratidae and Lyelliceratidae. Among the Heteromorpha, the Hamitidae and Ptychoceratidae are represented (Figure 1). The identified species and subspecies are:

Phylloceras (Hypophylloceras) cf. subalpinum (d'Orbigny) Plate 1, Figure 4; Phylloceras (Hypophylloceras) cf. seresitense tanit Pervinquière (Plate 1, Figure 3); Phylloceras (Hypophylloceras) $\mathrm{cf}$. velledae velledae (Michelin) (Plate 1, Figure 2); Phylloceras (Hypophylloceras) cf. aphrodite Fallot and Termier (Plate 1, Figure 1); Beudanticeras sp. (Plate 2, Figure 3); Beudanticeras newtoni Casey (Plate 2, Figure 2); Parasilesites kilianiformis (Fallot) (Plate 2, Figure 1); Lyelliceras lyelli (d'Orbigny) (Plate 2, Figure 5); Hypacanthoplites milletianus (d'Orbigny) (Plate 2, Figure 4); Hamites attenuatus J. Sowerby (Plate 2, Figure 6); and Ptychoceras $\mathrm{cf}$. laeve Matheron (Plate 2, Figure 7).

With 8 specimens, the Phylloceratidae dominate the assemblage and represent 44 per cent of the total Albian ammonites collected. The Desmoceratidae are second in abundance, with 5 specimens representing 28 per cent. The re-

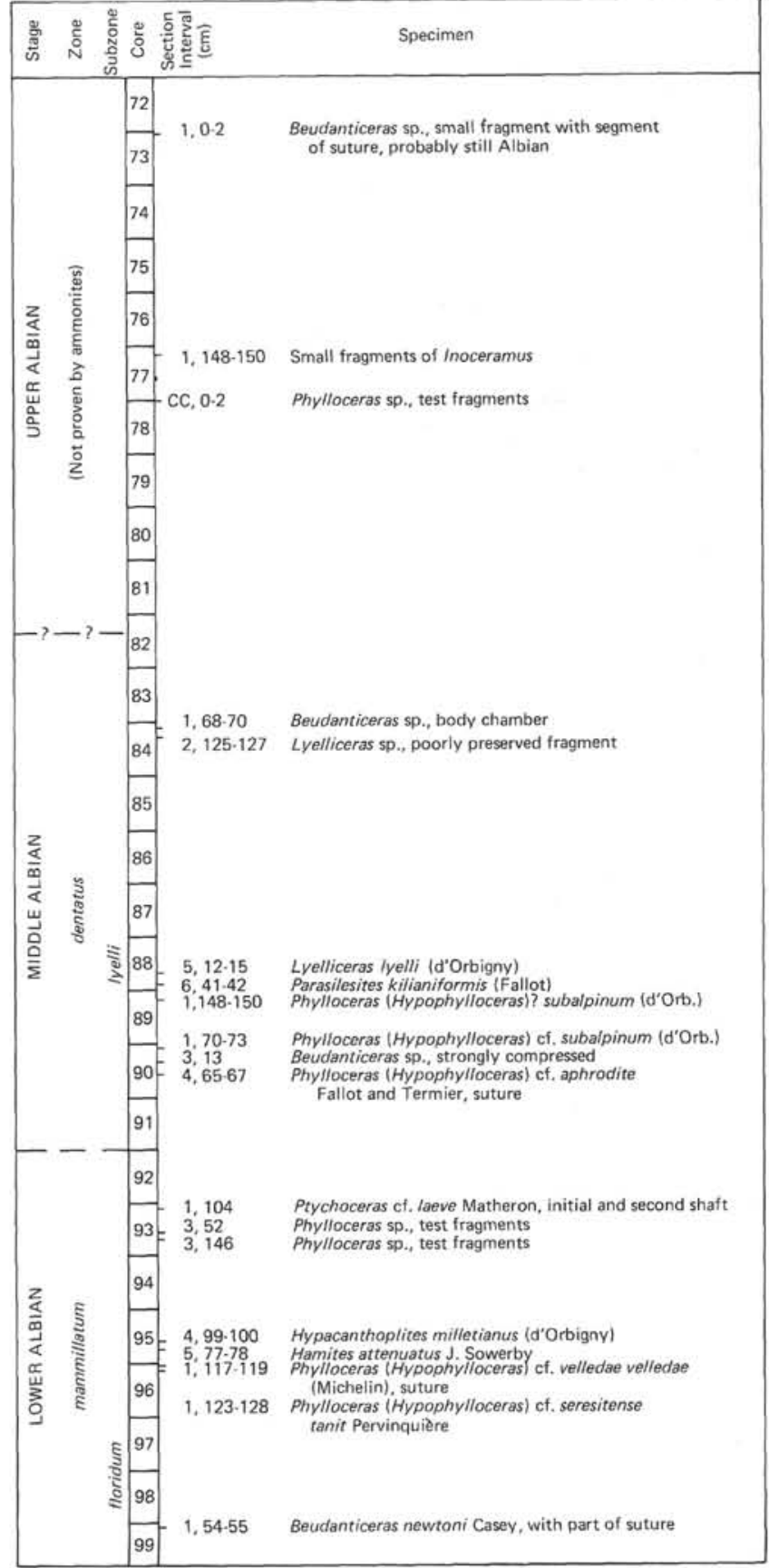

Figure 1. Distribution of ammonites in the Albian sediments of Leg 47B, Hole 398D.

maining five specimens are distributed among the genera Hypacanthoplites, Lyelliceras, Hamites, and Ptychoceras (28 per cent of the total). 


\section{Upper Albian}

Within the interval of Cores 72 to $82(1120$ to $1220 \mathrm{~m})$, specifically unidentifiable fragments of tests of Phylloceras sp. (Sample 77-CC, 0-2 cm) and fragments showing segments of the suture indicating a Beudanticeras (Sample $73-1,0-2 \mathrm{~cm}$ ) are present. These remains do not permit reliable age determinations. The presence of Beudanticeras at the top of Core 73 suggests, however, an Albian age for the interval; according to its position in the section, these sediments are considered upper Albian.

\section{Middle Albian}

The middle Albian ammonites are better preserved and allow more accurate age determinations. This interval is represented by Cores 82 to 91 (1220 to $1310 \mathrm{~m})$. Within the middle Albian, the following three ammonite zones are established: the Euhoplites lautus, the Euhoplites loricatus and the Hoplites dentatus zones (Owen, 1971). The ammonites in our samples are confined to the dentatus Zone, which again is subdivided into three subzones. One of these, the Lyelli Subzone (Figure 1), is ascertained in Core 88 $(1270 \mathrm{~m})$ by the presence of a relatively well preserved specimen of Lyelliceras lyelli (d'Orbigny). This specimen is considered reliable evidence of middle Albian deposits. The middle Albian-lower Albian boundary seems fairly restricted between Cores 91 and 92 (1309 m).

\section{Lower Albian}

The established ammonite zones of the lower Albian are the Douvilleiceras mammillatum above, and the Leymeriella tardefurcata, below. Only the mammillatum Zone, which is subdivided into four subzones, is reliably represented in Hole 398D. The age-indicating ammonite of importance is Hypacanthoplites milletianus (d'Orbigny) derived from Sample 95-4, 99-100 cm (about $1340 \mathrm{~m}$ ). About 25 meters deeper, Beudanticeras newtoni Casey occurs in Sample 99-1, 54-55 cm (1365 m). In southern England, this species attains its greatest frequency within the floridum Subzone (the third of the four succeeding subzones) of the mammillatum Zone.

Only a minute share of the Albian ammonite fauna in this area was recovered from Hole 398D. Abundant Phylloceratidae and Desmoceratidae, and the absence of strongly ornamented Hoplitidae suggest an open basin Albian environment. Comparable depositional environments are known from Mallorca (Fallot, 1910, 1920) and from southern Spain in the Alicante region, where the faunal character is also dominated by the Phylloceratina. Similar assemblages composed of Lyelliceras, abundant Beudanticeras, and Tetragonites occur in the Andean Geosyncline, especially in the Cordillera del Interior of Venezuela.

\section{APTIAN}

No Aptian ammonites were recognized at Hole 398D. And as yet undescribed fragmentary Lamellaptychus from Sample $105-3,84 \mathrm{~cm}(1423 \mathrm{~m})$ is the only larger fossil collected (Plate 2, Figure 8). Evaluation of the importance of this find requires comparison with finds from future drilling.

\section{BARREMIAN}

Three strongly compressed Barremian ammonites, also with their tests preserved, occurred between Cores 127 and 130 (1636 to $1663 \mathrm{~m}$ ), 243 meters below the deepest Albian ammonite. The genus Barremites is represented by two specimens, which are accompanied by a juvenile Protetragonites; all are specifically unidentifiable. Barremites is widely distributed between southern England and northern Africa, and several species from the Barremian of the Alicante region in southern Spain are described by Lillo Bevia (1975 a,b).

\section{HAUTERIVIAN}

The presence of Hauterivian deposits is suggested by a single, favorably preserved Lamellaptychus angulocostatus (Peters). This specimen (Plate 2, Figure 9) occurs in Core $136,22.5$ meters above the bottom of the hole. In the North Atlantic, L. angulocostatus has been recorded in several DSDP holes: from Hole 105 (Core 18, pl. 4, fig. 1-5) in the Hatteras Abyssal Plain, Leg 11 (Renz, 1972); Hole 367 (Core 26, pl. 1, fig. 34, 35; Core 27, pl. 2, fig. 1-4) in the Cape Verde Basin, Leg 41 (Renz, 1977); and from Hole $391 \mathrm{C}$ (Cores 14 to 17 , pl. 1, fig. 16, 17) in the BlakeBahama Basin, Leg 44 (Renz, in press).

\section{SYSTEMATIC DESCRIPTIONS}

The ammonites were received in June 1976 from Jacques Sigal who collected them on-board ship during Leg 47B. The material was still moist, and disintegrated rapidly when unpacked. Measures had to be taken immediately to avoid further disintegration of the claystone, separation of the fossils from the matrix, and breakage of the ammonite tests.

Without exception, all ammonites had their tests well preserved and little diagenetical alteration occurred. The composition of test material from a Hamites attenuatus J. Sowerby (Sample 95-5, 77-78 cm) was analyzed by $\mathrm{X}$-ray diffraction by S. Graeser, mineralogist of the Museum. The DebyeScherrer diagram clearly shows that the test material is absolutely identical with aragonite. The appearance of the test is mother of pearl-like, brilliant light brown, and without visible traces of original color.

This type of preservation is typical for shale-clay sequences, where diagenetic exchange of shell material by solution is reduced to a minimum. During sinking to the sea bottom, only the thin outer layer of the test, containing color pigment, was removed. The aragonite of the conch was not affected by solution, nor was it transformed into calcite. We assume that the recovered ammonites did not live near the bottom of the sea, where they presently form part of a death community (thanatocoenosis). The conchs were probably rapidly buried by shale or turbidite flows. According to Friedman (1965), pteropod shells composed of aragonite apparently dissolve at a water depth of about 3500 meters. We might assume that the water depth during the Albian at Site 398D was considerably above this depth.

The internal structure of the test is clearly observable on several specimens, especially Phylloceratidae. On lamellae forming the outer layer of the test, spirally arranged bends displaying feather structures have been occasionally noticed (Plate 1, Figure 1a). The prismatically structured thin inner layer is generally well preserved.

Most of the ammonite conchs have been crushed and flattened by compaction of the sediment. Some tests are broken into innumerable small fragments (Ptychoceras sp., Plate 2, Figure 7); some are strongly bent, especially less resistant phragmocons (? Protetragonites, Plate 1, Figure 5). The venters of thin-shelled Phylloceras and Beudanticeras are the most strongly affected. Nevertheless, suture lines sometimes remain recognizable and were freed by removing the test fragments. This was done on several Phylloceras (Plate 1, Figure 4), as well as Barremites (Plate 1, Figure 7), which otherwise never could have been determined. Fortunately, some ornamented species as Lyelliceras lyelli (d'Orbigny) and Hypacanthoplites milletianus (d'Orbigny), which are more resistant to compaction, are less deformed and more readily identified. 
Family PHYLLOCERATIDAE Zittel, 1884

Genus PHYLLOCERAS Suess, 1865

Subgenus HYPOPHYLLOCERAS Salfeld, 1924

The subdivisions of the subgenus Hypophylloceras are based on the development of the suture lines as established by Wiedmann (1963).

Specific determinations of the specimens remain tentative; they are based mainly on the suture and the sculpture as determinable by the stage of preservation. Whorl sections, however, could not be considered because of the deformation of the conchs.

\section{Group of Phylloceras (Hypophylloceras) thetis (d'Orbigny)}

This group is distinguished by a diphylloid pattern of the two main saddles through all stages of their development (Wiedmann, 1963, p. 173).

Phylloceras (Hypophylloceras) cf. aphrodite Fallot and Termier (Plate 1, Figure 1a, 1b)

1923 Phylloceras aphrodite Fallot and Termier, p. 25, pl. 2, fig. 5-7. 1963 Phylloceras (Hypophylloceras) aphrodite Fallot and Termier, Wiedmann, p. 184 , pl. 18 , fig. $4-6$; pl. 20, fig. 1 ; text-fig. 40 .

1975 Phylloceras (Hypophylloceras) aphrodite Fallot and Termier, Lillo Bevia, p. 398, pl. 2, fig. 1, 2.

Neotype: Wiedmann, 1962, pl. 16, fig. $5 ; 1963$, pl. 18, fig. 4.

Sample $90-4,65-67 \mathrm{~cm}$ is a compressed fragment, representing the end of the phragmocon (indicated by arrow) of a fairly large specimen (diameter after reconstruction, about $40 \mathrm{~mm}$ ). The diameter of the umbilicus is $3.2 \mathrm{~mm}(0.08)$, compared with 0.07 of the neotype with a diameter of 50 $\mathrm{mm}$. Two of the constrictions directed adorally are slightly recognizable. No clear riblets, but faint growth lines are preserved on the external side of the whorl. Suture shows clear diphylloid saddles, which coincide in detail with those of $P h$. aphrodite as shown by Wiedmann (1963, p. 185, fig. 40).

The specimen was collected 17.5 meters below Lyelliceras lyelli. Its age, therefore, is early middle Albian.

Ph. aphrodite is known from Mallorca and the Alicante region, from France (Breistroffer, 1947), and from Sinai (Mahmoud, 1955, pl. 5, fig. 1).

\section{Phylloceras (Hypophylloceras) cf. subalpinum (d'Orbigny)} (Plate 1, Figures $4 \mathrm{a}, 4 \mathrm{~b}$ )

1963 Phylloceras (Hypophylloceras) subalpinum d'Orbigny, Wiedmann,

p. 194.

Sample 90-1, 70-73 cm, the largest Phylloceras of the collection, is best comparable with $P h$. (H.) subalpinum. The latter can be distinguished into two subspecies: $P h$. (H.) subalpinum subalpinum d'Orbigny) characterized by a subtriangular whorl section, and $P h$. $(H$.) subalpinum ellipticum Kossmat, characterized by an elliptical whorl section. The features of these subspecies are otherwise identical. Because of compression, it is not possible to attribute the present speciment to one of the two subspecies.

The specific features exposed on the test are radial, sigmoidal, broad, flat folds, and closely spaced growth lines passing towards the venter into faint riblets. By removing part of the test along the end of the phragmocon, the next inner whorl appeared immediately beneath, exposing part of the diphyloid suture line. The preserved portion of the specimen coincides satisfactorily with the suture of $P h$. $(H$.) subalpinum subalpinum d'Orbigny) from Mallorca, drawn by Wiedmann (1963, p. 196, fig. 45).

The specimen was collected 6 meters above $P h .(H$.$) cf. aphrodite and$ 12.5 meters below Lyelliceras lyelli; the interval, therefore is middle Albian.

Sample $89-1,184-150 \mathrm{~cm}$ yields the badly crushed remains of test showing parts of diphylloid saddles, similar to those on $P h$. $(H$.) subalpinum subalpinum.

\section{Group of Phylloceras (Hypophylloceras) velledae (Michelin)}

The suture is characterized by a diphylloid saddle $\mathrm{L} / \mathrm{E}$ and a tetraphylloid saddle $\mathrm{L} / \mathrm{U}_{2}$ (Wiedmann, 1963, p. 173, 204).

\section{Phylloceras (Hypophylloceras) cf. velledae velledae (Michelin)} (Plate 1, Figures 2a, b)

1963 Phylloceras (Hypophylloceras) velledae velledae (Mich.), Wiedmann, p. 209, pl. 11, fig. 1 ; pl. 13, fig. 4 ; pl. 21, fig. 4; suture, text-fig. 49.
Neotype: Ammonites velledae Michelin, in d'Orbigny, 1841 , pl. 82 , fig. $1,2$.

Sample $96-1,117-119 \mathrm{~cm}$ is a rather small, somewhat less compressed specimen with its venter partially preserved. This specimen is similar to a juvenile $P h$. (H.) velledae velledae as figured by Wiedmann (1963, pl. 21, fig. 4). A reconstruction of the whorl section was attempted with the help of a cast of the preserved impression. The resulting measurements are: diameter, $23 \mathrm{~mm}$; whorl height, $14 \mathrm{~mm}(0.60)$; whorl width, $7 \mathrm{~mm}(0.30)$; $\mathrm{Ww} / \mathrm{Wh}=0.50$ compared with 0.62 for the neotype (Wiedmann, 1963, p. 212).

The whorl section is high oval, the venter is broadly rounded, and the flanks are weakly arched with their maximal width slightly below the middle of the flank. The umbilicus is very narrow and funnel shaped. The test is covered by faint growth lines, developing into riblets towards the venter. The suture is incompletely preserved. The saddle $\mathrm{L} / \mathrm{U}_{2}$ is beginning to be tetraphylloid (compare Weidmann, 1963, fig. 49a, p. 211).

The specimen was extracted 4.7 meters below Hypacanthoplites milletianus d'Orbigny), which indicates early Albian (mammillatum Zone).

\section{Group of Phylloceras (Hypophylloceras) seresitense Pervinquiére}

The suture of this group is characterized by a tetraphylloid saddle $L / E$ as well as $\mathrm{L} / \mathrm{U}_{2}$.

Phylloceras (Hypophylloceras) cf. seresitense tanit Pervinquiére (Plate 1, Figures 3a, 3b).

1963 Phylloceras (Hypophylloceras) seresitense tanit Perv., Wiedmann, p. 226, pl. 21, fig. 2, 3; suture, text-fig. 54a.

1968 Phylloceras (Hypophylloceras) seresitense tanit Perv., Wiedmann and Dieni, p. 26, pl. 1, fig. 6; pl. 3, fig. 1.

Holotype: Phylloceras tanit Pervinquiére, 1907, text-fig. 5; pl. 3, fig. $6,7$.

Sample 96-1, 123-128 cm yields a specimen with a diameter of $44 \mathrm{~mm}$ which is one of the better-preserved ammonites of the collection. Its suture is too indistinctly preserved to be reproduced, so the determination had to be based on morphological features. By its considerably wider umbilicus (Plate 1, Figure 3b) of $4.6 \mathrm{~mm}(0.10)$, this specimen differs from $P h$. seresitense serisitense Pervinquiére. The ornamentation on the test is well preserved, and characterized by bi-convex growth lines developing into prominent riblets towards the venter. The present specimen closely resembles those figured by Wiedmann (1963, p. 228, fig. 54b) from Mallorca, and by Wiedmann and Dieni (1968, pl. 1, fig. 6) from Sardenia.

$P h$. $(H$.) serisitense tanit is widely found in western Europe and occurs in North Africa, Madagascar, India, and Mexico (Böse, 1923, p. 119, pl. 7, fig. 15-17).

\section{Family PROTETRAGONITIDAE Spath, 1927}

(Plate 1, Figure 5)

Sample 129-7, 18-20 cm yields a small Barremian specimen (diameter of $18 \mathrm{~mm}$ ), possibly related to the genus Protetragonites, that was found in the vicinity of Barremites sp. Except for faint growth lines on the test, neither sculpture (constrictions) nor signs of the suture could be detected.

\section{Family DESMOCERATIDAE Zittel, 1895}

\section{Subfamily EODESMOCERATINAE Wright, 1955}

Genus BARREMITES Kilian, 1913

\section{Barremites sp.}

(Plate 1, Figures 7a, 7b.)

Sample 128-1, 61-65 $\mathrm{cm}$ provided the test of a flattened quarter whorl that is broken into numerous fragments. Removing the test revealed part of the suture and facilitated a generic determination (see arrow). Reconstruction of the whorl section along the external side of the core is doubtful, but it is obviously elongate-ovate. The flank seems gently arched (based on larger single-test fragments), and the umbilical wall falls off steeply towards an involute umbilicus. Except for sinuous growth lines on the test, no signs of sculpture (constrictions) are detectable. The suture satisfactorily coincides with that drawn by Roman (1938, p. 408 , fig. 388 ) of a Barremites.

The genus occurs worldwide. The nearest occurrence to Site 398 is found in the Alicante region of southern Spain (Lillo Bevia, $1975 \mathrm{a}, \mathrm{b}$ ). 
Barremites sp.

(Plate 1, Figure 6)

Sample 130-3, $105 \mathrm{~cm}$ yields a flattened specimen that, except for its eccentric umbilicus, is comparable with the fragment previously described. The sculpture is restricted to sinuously bent growth lines.

\section{Subfamily PUZOSIINAE Spath, 1922}

\section{Genus PARASILESTIES Imlay, 1959}

Parasilesites kilianiformis (Fallot)

(Plate 2, Figures 1a, 1b)

1910 Puzosia nolani var. kilianiformis Fallot, p. 26, pl. 1, fig. 5.

1920 Puzosia nolani var. kilianiformis Fallot, p. 46.

1947 Silesites kilianiformis Fallot, Breistroffer, p. 62.

1957 Silesites nolani var, kilianiformis (Fallot), Almela and De La Revilla, p. 28 , pl. 7 , fig. 3 .

1968 Parasilesites kilianiformis (Fallot), Wiedmann and Dieni, p. 124, pl.

10 , fig. 7 ; suture, text-fig. 79 , p. 125 .

Holotype: P. Fallot, 1910, pl. 1, fig. 5a, b.

Sample 88-6, 41-42 cm contains a small compressed specimen with a diameter of $22 \mathrm{~mm}$ and an umbilicus of $8 \mathrm{~mm}(0.36)$. The five braod, radial, periodic constrictions per whorl are somewhat more closely spaced than those on the well-preserved specimen from Sardenia with four constrictions per whorl. The fine ribs between the constrictions are also well exposed on the impression (Plate 2, Figure 1b).

The specimen was collected close to Lyelliceras lyelli, which indicates an early middle Albian age (dentatus Zone).

The species Parasilesites bullatus Imlay (1959, p. 184, pl. 29, fig. 1-8; 1960, pl. 18, fig. 1-8) from the Albian of Alaska shows distinctly more constrictions per whorl than this specimen.

\section{Subfamily BEUDANTICERATINA Breistroffer, 1953}

\section{Genus BEUDANTICERAS Hitzel, 1905}

Four ammonites referred to Beudanticeras are distributed over the Albian interval, indicating a rich development of the genus in this claystone environment. Besides Beudanticeras newtoni Casey, the preservation is so poor that accurate determinations are not possible.

Sample 73-1, 0-2 cm has a fragment with the suture preserved. Considered a Beudanticeras, this find is the uppermost ammonite occurrence at this site.

\section{Beudanticeras sp. \\ (Plate 2, Figure 3)}

Sample 84-1, 68-70 $\mathrm{cm}$ yields a fragment of a body chamber that appears to be a large Beudanticeras (whorl height of about $35 \mathrm{~mm}$ ). The ornament consists of well-marked, falcoid growth lines, and one of the broad, prominent, falcoid constrictions characterizing the body chamber of adult specimens. The small, irregular, subcircular deepenings adorally from the constriction probably were the result of boring organism.

The fragment was extracted in the vicinity of a Lyelliceras and, therefore, is considered middle Albian (dentatus Zone).

Sample 90-3, $13 \mathrm{~cm}$ contains a flattened Beudanticeras (diameter $24 \mathrm{~mm}$ ) that was sampled 15 meters below Lyelliceras lyelli, thus indicating the lyelli Subzone of the middle Albian. The septa are partly crushed into a brecciated mass such that only fragments of the suture are recognizable.

\section{Beudanticeras newtoni Casey}

(Plate 2, Figures 2a, 2b)

1961 Beudanticeras newtoni Casey, p. 147, pl. 26, fig. 12; pl. 27, fig. 2-5; pl. 28, fig. 7, 8; pl, 29, fig. 2; text-fig. 47a-b, c, e, f.

Holotype: Casey, 1961, text-fig. 47 a, b, p. 150.

Sample $99-1,54-55 \mathrm{~cm}$ contains a slightly compressed ammonite that is best comparable to the Beudanticeras newtoni figured by Casey (1961, pl. 29, fig. 2). The latter specimen occurs in the mammillatum Zone (nodulebeds, floridum Subzone, Squerrye's main pit, Westerham, Kent).

With a diameter after reconstruction of $32 \mathrm{~mm}$, a whorl height of $15.2 \mathrm{~mm}$ $(0.47)$, and an umbilicus of $6.3 \mathrm{~mm}(0.20)$, this find compares well with the measurements obtained by Casey. The whorl section is highly elliptical and widest toward the inner quarter of the flank. The umbilical rim is sharply expressed, the umbilical wall falls off steeply toward the fairly narrow umbilicus, and the umbilical spiral is distinctly eccentric. Sculpture on test consists of fine growth lines and widely spaced, broad, falciform ridges increasing in strength adorally. The suture was only partially freed to avoid destruction of the test.

Beudanticeras newtoni is the oldest ammonite recovered from the Albian within this hole. Occurring 31 meters below Hypacanthoplites milletianus (d'Orbigny) of the lower Albian, this specimen might indicate the raulinianus to floridum subzones, where $B$. newtoni reaches its maximum abundance in southern England (Casey, 1961, p. 152).

\section{Family DOUVILLEICERATIDAE Parona and Bonarelli, 1897}

\section{Genus HYPACANTHOPLITES Spath, 1923}

\section{Hypacanthoplites milletianus (d'Orbigny)}

(Plate 2, Figures $4 \mathrm{a}, 4 \mathrm{~b}, 4 \mathrm{c}$ )

1841 Ammonites milletianus d'Orbigny, p. 263, pl. 77, fig. 1, 2. 1947 Hypacanthoplites milletianus d'Orbigny, Breistroffer, p. 40 1964 Hypacanthoplites milletianus (d'Orbigny), Casey, p. 433, p. 40, pl. 73 , fig. 7a-b; text-fig. 160 .

Lectotype: d'Orbigny, 1841, pl. 77, fig. 1, 2; Casey, 1965, text-fig. $160 f, \mathrm{~g}$

Sample $95-4,99-100 \mathrm{~cm}$ contains a favorably preserved specimen showing a juvenile whorl, as well as a fragment of the adult whorl that is oblique to the bedding and covers part of the juvenile whorl. The whorls resisted compaction because of this configuration.

Ribs on the juvenile whorl are alternately long and short and faintly sinous. The longer ones begin from pronounced umbilical tubercles, from which a branching of the ribs also can occur. The adult whorl fragment is subquadrate in section. The specimen is slightly higher than wide, with maximum thickness just above the umbilicus (Plate 2, Figure 4c). The flanks are weakly convex, converging towards a flat venter. This specimen exhibits coarse and rigid costation, and alternately long and short ribs. The short ribs begin within the dorsal third of the flank.

Except for its coarser costation, the specimen is very similar to Hypacanthoplites trivialis Breistroffer (1947, p. 84).

H. milletianus seems to be restricted to the early Albian (compare Casey, 1964 , p. 435).

\section{Family LYELLICERATIDAE Spath, 1921}

\section{Genus LYELLICERAS Spath, 1921}

\section{Lyelliceras lyelli (d'Orbigny)}

(Plate 2, Figures 5a, 5b)

1897 Acanthoceras lyelli Deshayes (in Leymerie, 1842), Parona and Bonarelli, p. 96, pl. 13, fig. 7-12.

1931 Lyelliceras lyelli (d'Orbigny), Spath, p. 316, pl. 32, fig. 9, 12, 13; text-fig. 103.

1971 Lyelliceras lyelli (d'Orbigny), Owen, pl. 2, fig. 2a, b.

Lectotype: d'Orbigny, 1841 , pl. 74, fig. 4.

Sample $88-5,12-15 \mathrm{~cm}$ yields a conch filled with a hard aggregate of pyrite crystals formed prior to compression, thereby enabling the fossil to resist compaction. We removed the pyrite and made a cast (Plate 2, Figure $5 a)$. The venter with syphonal tubercles is not preserved. Lyelliceras pseudolyelli Parona and Bonarelli $(1897$, p. 99, pl. 14, fig. 1, 2) differs from this species by wider spaced ribs and alternating tubercles on the venter.

L. lyelli indicates the lyelli Subzone of the dentatus Zone and, therefore, is of considerable value for a subdivision of the Albian interval.

Lyelliceras is widely distributed in western Europe and northern Africa, as well as in the Andean Geosyncline: Peru (Schlagintweit, 1911, p. 87) Colombia, Venezuela (Guillaume et al., 1972, p. 1653), and Mexico (Böse, 1923 , p. 160 , pl. 11, fig. 1-3).

\section{Lyelliceras sp.}

Sample 84-2, 125-127 cm contains the dorsal half of a larger whorl fragment. Impressions of syphonal tubercles from the next inner whorl are visible.

\section{Family HAMITIDAE Hyatt, 1900}

Genus HAMITES Parkinson, 1811

Hamites (Hamites) attenuatus J. Sowerby (Plate 2, Figures 6a, 6b) 
1941 Hamites attenuatus J. Sowerby, Spath, p. 607, pl. 67, fig. 1-13, 19; test-fig. 218 .

Lectotype: J. Sowerby, 1814, pl. 61, fig. 4, refigured by Spath, 1941, text-fig. 218.

Sample 95-5, 77-78 cm yields a compressed but otherwise favorably preserved example of this species, common in the middle Albian (dentatus and lautus Zones) of southern England.

According to less compressed parts of the test, the whorl section seems to have been broadly oval. The obliquity of the ribbing is less pronounced than on specimens from England reproduced by Spath (1941).

The stratigraphical position of $H$. attenuatus, close to Hypacanthoplites milletianus (d'Orbigny) and 56 meters below Lyelliceras lyelli (d'Orbigny) of the middle Albian, indicates a late early Albian date for this specimen (mammillatum Zone).

\section{Family PTYCHOCERATIDAE Meek, 1876}

\section{Genus PTYCHOCERAS d'Orbigny, 1842}

Ptychoceras of. laeve Matheron

(Plate 2, Figures 7a-7c)

Holotype: P. Matheron, 1842, p. 338, pl. 41, fig. 3.

Sample 93-1, $104 \mathrm{~cm}$ yields this small fragment that is comparable with the holotype of $P$. laeve from the upper Aptian (Gargasien) from Cassissur-Mer (Bouches-du-Rhône) in southern France (Breistroffer, 1951, p. 47). The hook between the initial and second shaft is present. The initial shaft leans closely against the second shaft, but whether it is pressed into the dorsum of the second shaft cannot be ascertained. The surface of the test is smooth, traces of constrictions or ribs cannot be detected. The suture is characterized by simple bifid lobes and saddles.

Busnardo (1957, p. 57) mentions $P$. laeve from lower Albian marls with Hypacanthoplites in the Constantine region in Algeria.

Ptychoceras laeve hamaimensis has been described by Pervinquiére (1907, p. 90, pl. 4, fig. 5-6) from the lower Albian of Tunisia, where it occurs with Hypacanthoplites. This subspecies possesses constrictions on the second shaft and may be related with the present specimen.

Ptychoceras mazapilense (Burckhardt) from the Albian of Zacatecas in Mexico (Böse, 1923, p. 137, pl. 10, fig. 1-8) is also small, and seems to be related to the present species.

From the Serrania del Interior in Eastern Venezuela, $P$. laeve has been identified from the upper Aptian Cheloniceras martini Zone (Guillaume et al., 1972, p. 1653)

\section{ACKNOWLEDGMENTS}

I am especially grateful to Dr. Jacques Sigal, who collected the material and brought it to the Museum of Natural History in Basel. Furthermore, I want to thank Dr. Jean-Claude Sibuet, Co-Chief Scientist, for having reviewed the manuscript. The photographic work was done by W. Suter from the Museum.

\section{REFERENCES}

Almela, A. and De La Revilla, J., 1957. Fósiles piritosos del Cretáceo de la Sierra de Ricote (Murcia), Bol. Inst. Geol. Minero España, v. 68, p. 45-83.

Böse, E., 1923. Algunas faunas cretácicas de Zacatecas, Durango y Guerrero, Inst. Geol. Mexico, Bol. 42, p. 219.

Breistroffer, M., 1947. Sur les zones d'ammonites dans l'Albien en France et d'Algleterre, Trav. Lab. Géol. Grenoble, v. 26, p. 88 .

1951. Sur la position systématique du genre Ptychoceras d'Orb, Trav. Lab. Géol. Grenoble, v. 29, p. 47-54.

Busnardo, R., 1957. Etude stratigraphique des marnes á Ammonoidés de la région de Constantine, Publ. Serv. Carte Géol. Algérie. Bull. 13, p. 7-65.

Casey, R., 1961. The Ammonoidea of the Lower Greensand, III, Palaeontol. Soc., p. 119-216.

1964. The Ammonoidea of the Lower Greensand, VI, Palaeontol. Soc., p. 399-546.

Collignon, M., 1932. Les ammonites pyriteuses de L'Albien supérieur du Mont Raynaud á Madagascar, Ann. géol. Serv. Mines. p. 5-36.

Fallot, P., 1910. Quelques fossiles pyriteux du Gault des Baléares, Ann. Univ. Grenoble, v. 22, p. 1-33.
1920. La faune des marnes aptiennes et albiennes de la région D'Andraitx (Majorque), Mus. Nac. Ci. nat., ser. geol., Madrid, v. 26, p. 1-68.

Fallot, P. and Termier, H., 1923. Ammonites nouvelles des Iles Baléares, Mus. Nac. Ci. nat., ser. geol., Madrid, v. 32, p. 1-83.

Friedman, G.M., 1965. Occurrence and stability relationships of aragonite, high-magnesium calcite and low-magnesium calcite under deep-sea conditions, Geol. Soc. Am., Bull., v. 76, p. 1191-1195.

Guillaume, H.A., Bolli, H.M., and Beckmann, J.P., 1972. Estratigrafia del Cretáceo Inferior en la Serrania del Interior, Oriente de Venezuela, Bol. Geol., Caracas, p. 1619-1658.

Imlay, R.W., 1959. New genera of early Cretaceous (Albian) ammonites from Alaska, J. Paleontol., v. 33, p. 179-185. 1960. Early Cretaceous (Albian) ammonites from the Chitina Valley and Talkeetna Mountains, Alaska, Geol. Surv. Prof. Papers, v. 354-D, p. 87-114.

Lillo Bevia, J., 1975a. Ammonitas del sur de Alicante: I. Phylloceratina, Estudios geol., Inst. "Lucas Mallada," v. 31, p. $397-421$.

, 1975b. Sobre algunos Desmoceratacae (Ammonitina) del Cretácico Inferior del sur de Alicante, Estudios geol., Inst. “Lucas Mallada," v. 31, p. 681-704.

Matheron, P., 1842. Catalogue méthodique et descriptif des corps organisés fossiles du département des Bouches-du-Rhône et lieux circonvoisins., Marseilles, p. 1-269.

Orbigny, d'A., 1840-42. Paléontologie Française; Terrains Crétacés, I, Céphalopodes, p. 1-662.

Owen, H.G., 1971. Middle Albian stratigraphy in the Anglo-Paris Basin, British Mus. Bull. (Nat. Hist.), suppl. 8, p. 1-164.

Parona, C. and Bonarelli, G., 1897. Fossili albiani d'Escragnolles, del Nizzardo e della Liguiria occidentale. Paleontographia Italica, v. 2, p. 53-112.

Pervinquiére, L., 1907. Etudes de paléontologie tunisienne: I. Cephalopodes des terrains secondaires, Carte géol. Tunisie. p. $1-438$.

Renz, O., 1972. Aptychi (Ammonoidea) from the Upper Jurassic and Lower Cretaceous of the western North Atlantic, (Site 105, Leg 11, DSDP), In Hollister, C.D., Ewing, J.I., et al., Initial Reports of the Deep Sea Drilling Project, v. 11; Washington (U.S. Government Printing Office), p. 607-630.

1977. Aptychi (Ammonoidea) from the Late Jurassic and Early Cretaceaus of the Eastern Atlantic, DSDP Site 367. In Lancelot, Y., Seibold, E., et al., Initial Reports of the Deep Sea Drilling Project, v. 41: Washington (U.S. Government Printing Office), p. 499-514.

, 1978. Aptychi (Ammonoidea) from the Early Creta ceous of the Blake-Bahama Basin, Leg 44, Hole 391C, DSDP. In Benson, W.E., Sheridan, R.E., et al., Initial Reports of the Deep Sea Drilling Project, v. 44; Washington (U.S. Government Printing Office), p. 899-910.

Roman, F., 1938. Les Ammonites Jurassiques et Cretacées, Paris.

Schlagintweit, O., 1911. Die Fauna des Vracon und Cenoman in Peru, Beitr. Geol. u. Palaeont. Südamerika. N., Jb. Mineral. etc., Beil., v. 33, p. 43-135.

Sowerby, J., 1812-1823. The mineral conchology of Great Britain, v. 1-4, London.

Spath, L.F., 1923-1943. A monograph of the Ammonoidea of the Gault. Palaeontol. Soc., London, Parts 1-16.

Wiedmann, J., 1962. Ammoniten aus der Vascogotischen Kreide (Nordspanien). I. Phylloceratina, Lytoceratina, Palaeontographica (A), v. 118, p. 119-237.

1963. Unterkreide-Ammoniten von Mallorca. 2 Liefg.: Phylloceratina, Akad. Wiss. u. Lit., p. 151-264.

Wiedmann, J. and Dieni, I., 1968. Die Kreide Sardiniens und ihre Cephalopoden, Palaeontographia Italica, v. 64, p. 1-171. 


\section{PLATE 1}

Figure 1a

Figure 2a

Figure $2 b$

Figure 3a

Figure $3 b$

Figure 4a

Figure $4 \mathrm{~b}$

Figure 5

Figure 6

Figure 7a

Figure $7 b$
Sample 90-4, 65-67 cm. Phylloceras (Hypophylloceras) cf. aphrodite Fallot and Termier, J 28237. Arrow indicates end of phragmocon. Middle Albian. $1.5 \times$.

Suture at a whorl height of 20 to $22 \mathrm{~mm} .3 \times$.

Sample 96-1, 117-119 cm. Phylloceras (Hypophylloceras) cf. velledae velledae (Michelin), J 28238. Albian. $1.5 \times$.

Fragment of suture at a whorl height of about $8 \mathrm{~mm}$. $5 \times$.

Sample 96-1, 123 to $128 \mathrm{~cm}$. Phylloceras (Hypophylloceras) cf. seresitense tanit Pervinquiére, J 28239. Suture indistinct. Lower Albian. 1.5×.

Impression clearly showing the open umbilicus. $1.5 \times$.

Sample 90-1, 70 to $73 \mathrm{~cm}$. Phylloceras (Hypophylloceras) cf. subalpinum (d'Orbigny), J. 28240. The flat folds on the test are exposed on the fragment to the right, representing the end of the phragmocon, which overlaps on the fragment to the left (body chamber). Middle Albian. 1.5×.

Suture on the next inner whorl of the fragment to the left (arrow), at a whorl height of about $15 \mathrm{~mm}$. $5 \times$.

Sample $129-7,18$ to $20 \mathrm{~cm}$. ? Protetragonites sp., J 28241. Barremian. $1.5 \times$.

Sample 130-3, $105 \mathrm{~cm}$. Flattened Barremites sp., J 28242. Barremian. $1.5 \times$.

Sample 128-1, 61 to $65 \mathrm{~cm}$. Barremites sp., J 28243. Steep umbilical wall is prominent. Barremian. $1.5 \times$.

Suture (arrow) has been freed by removing crushed test fragments. Whorl height about $14 \mathrm{~mm}$. $5 \times$. 
PLATE 1

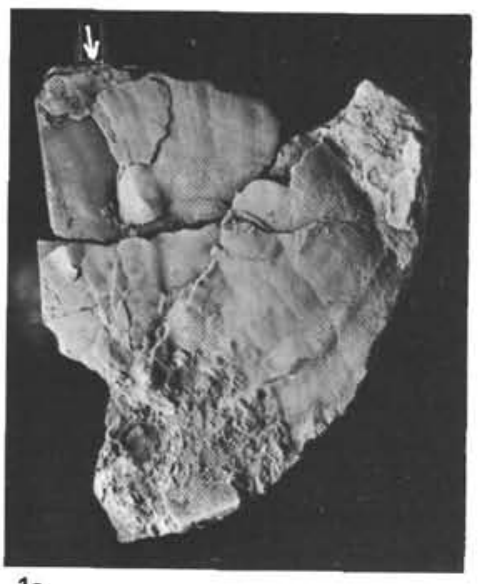

1a

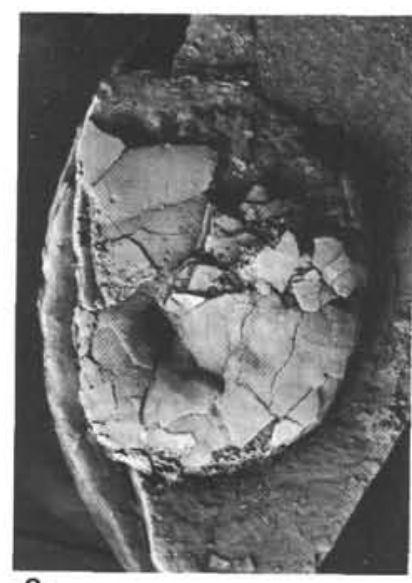

2a

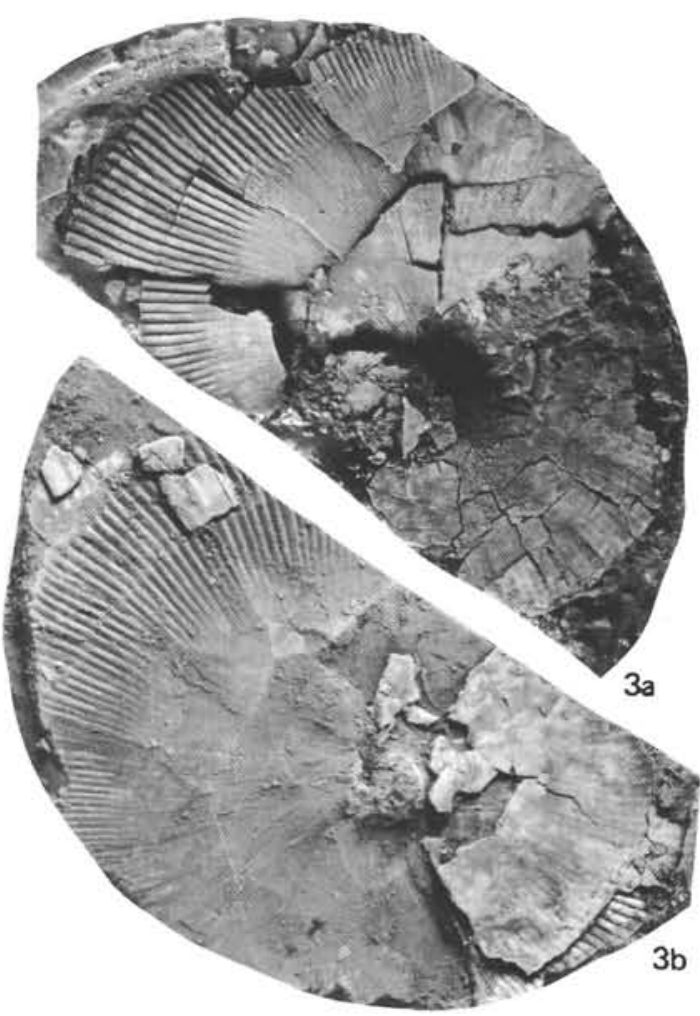

$1 \mathrm{~b}$
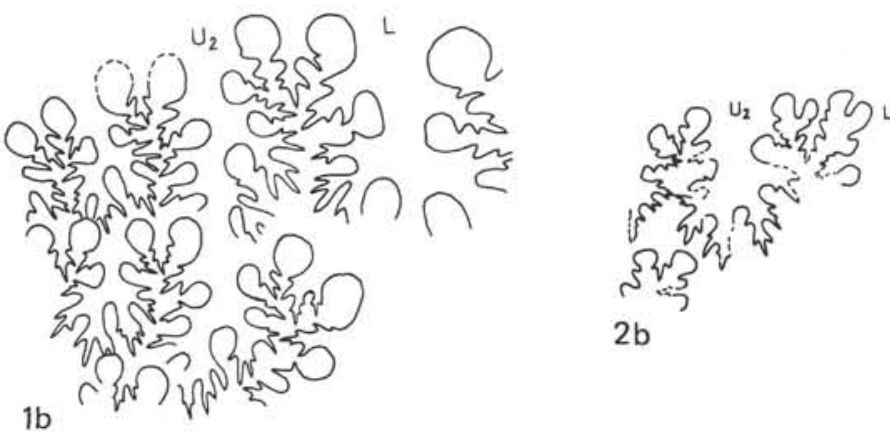

$2 b$

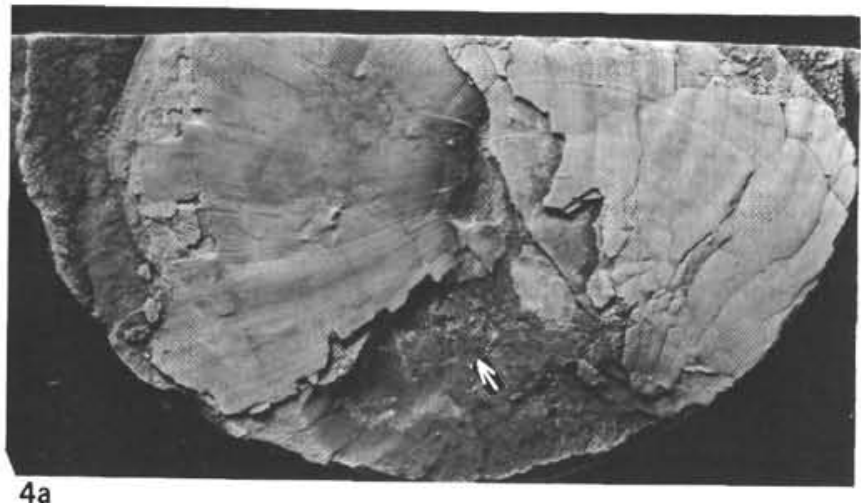

$$
\text { कb की }
$$
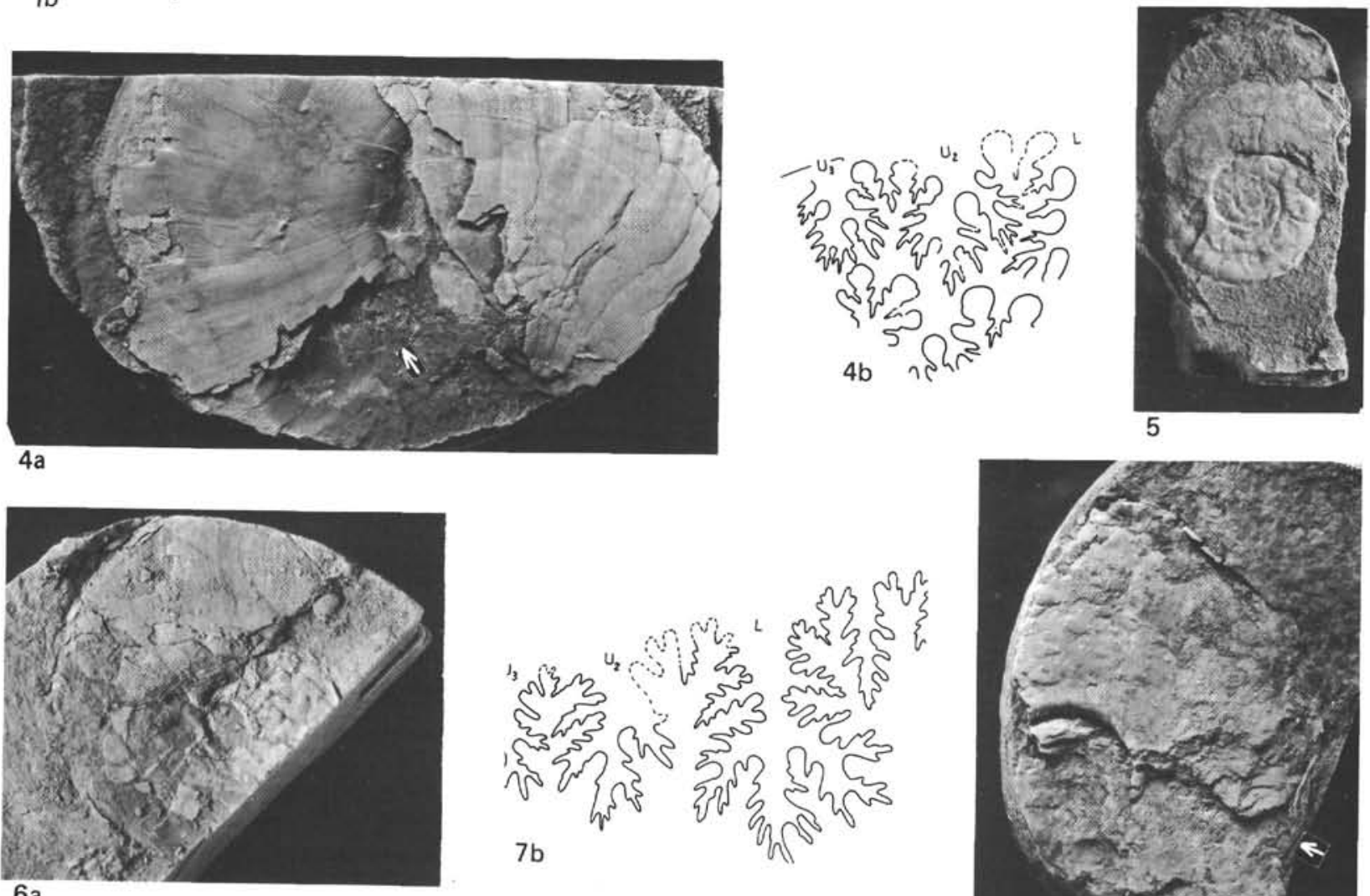

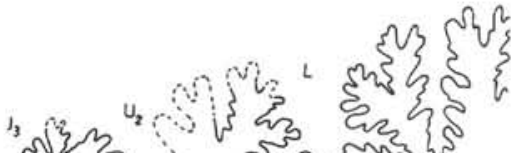
है।

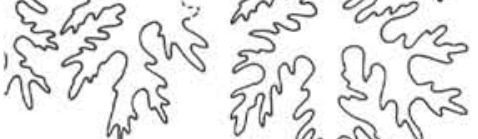
$7 b$

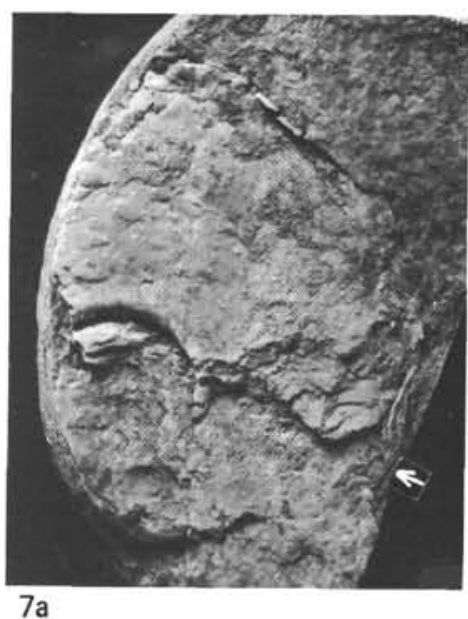




\section{PLATE 2}

Figure 1a Sample 88-6, 41 to $42 \mathrm{~cm}$. Parasilesites kilianiformis (Fallot), J 28244. Ribs between the constrictions are exposed clearly. Middle Albian. $1.5 \times$.

Figure 1b Impression showing fine ribs between constrictions. $1.5 \times$.

Figure 2a Sample $99-1,54$ to $55 \mathrm{~cm}$. Beudanticeras newtoni Casey, J 28245. Compare Casey, 1961, pl. 29, fig. 2. Middle Albian. $1.5 \times$.

Figure $2 \mathrm{~b} \quad$ Fragment of suture at a whorl height of $14 \mathrm{~mm} .5 \times$.

Figure 3 Sample 84-1, 68 to $70 \mathrm{~cm}$. Beudanticeras sp., J 28246. Body chamber of a large specimen. Middle Albian. $1.5 \times$.

Figure 4a Sample $95-4,99$ to $100 \mathrm{~cm}$. Hypacanthoplites milletianus (d'Orbigny), J 28247. Inner whorl, and fragment of adult whorl placed obliquely over the inner whorl. Lower Albian. $1.5 \times$.

Figure 4b Flattened venter, and angular shoulder of the adult whorl are visible. $1.5 \times$

Figure 4c Adult whorl section, partly reconstructed. $2 \times$.

Figure 5a Sample $88-5,12$ to $15 \mathrm{~cm}$. Lyelliceras lyelli (d'Orbigny), J 28248. Cast. Middle Albian. 1.5 ×.

Figure $5 \mathrm{~b} \quad$ Impression originally filled by pyrite crystals. $1.5 \times$.

Figure 6a Sample 95-5, 77 to $78 \mathrm{~cm}$. Hamites (Hamites) attenuatus J. Sowerby, J 28250. Lower Albian. 1.5×.

Figure $6 \mathrm{~b} \quad$ Fragmentary suture line.

Figure 7a Sample 93-1, $104 \mathrm{~cm}$. Ptychoceras cf. laeve Matheron, J 28249. Test fragments and suture. Lower Albian. $3 \times$.

Figure $7 \mathrm{~b} \quad$ Impression without traces of sculpture. $3 \times$.

Figure $7 \mathrm{c} \quad$ Fragments of suture lines. $5 \times$.

Figure 8 Sample 105-3, $84 \mathrm{~cm}$. Lamellaptychus sp., J 28220. Not determined, growth lines clearly visible. Probably Aptian. $3 \times$.

Figure 9 Sample 136-3, 92 to $94 \mathrm{~cm}$. Lamellaptychus angulocostatus (Peters), J 28251. Hauterivian. $3 \times$. 
PLATE 2

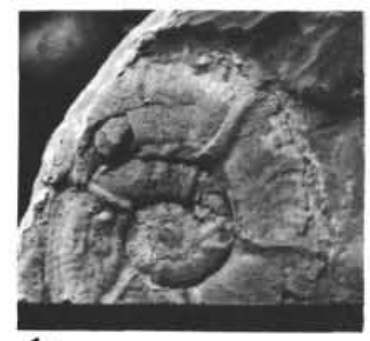

$1 \mathrm{a}$
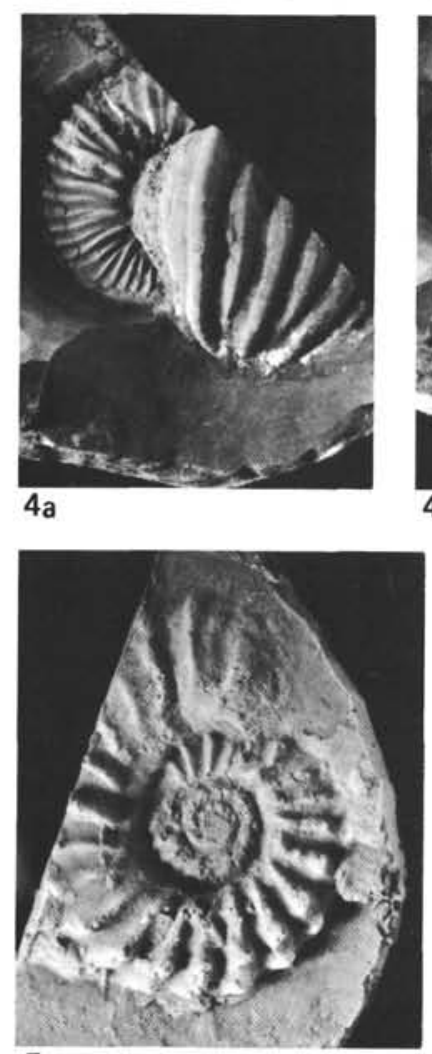

$5 a$

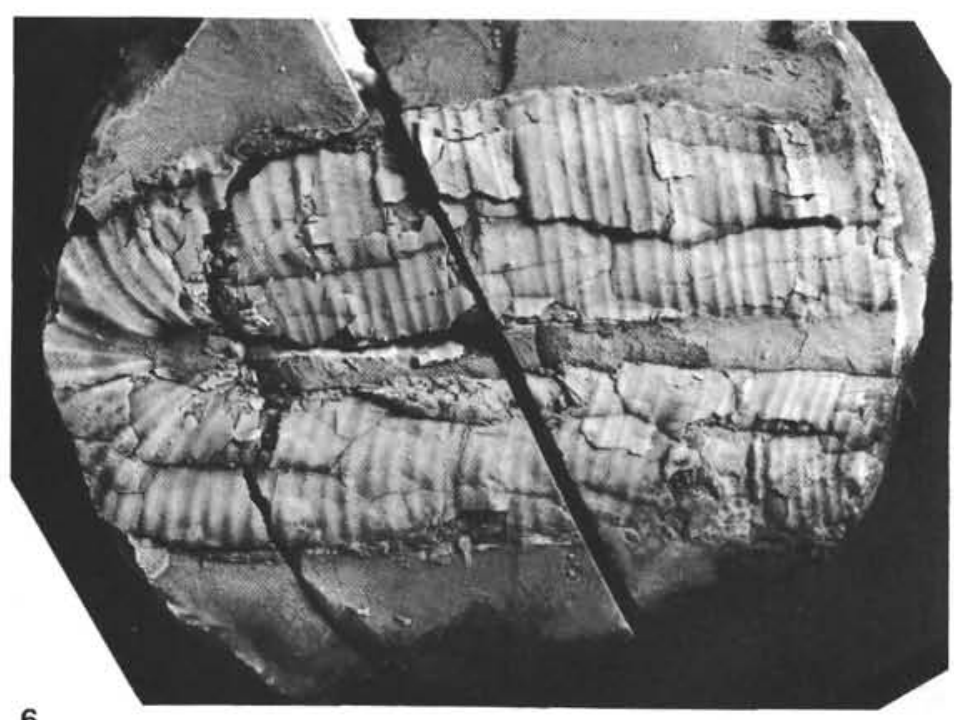

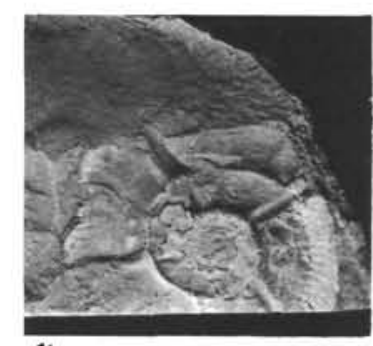

1b
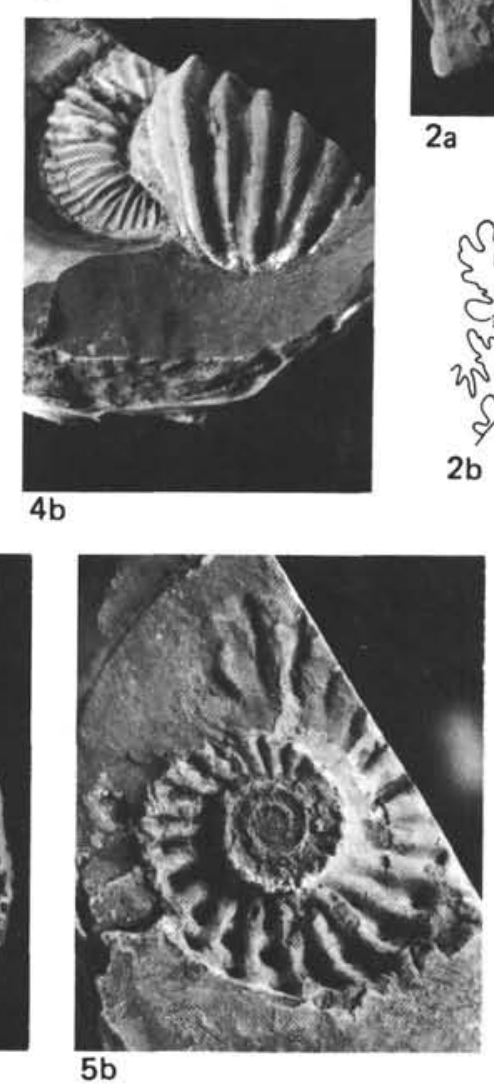
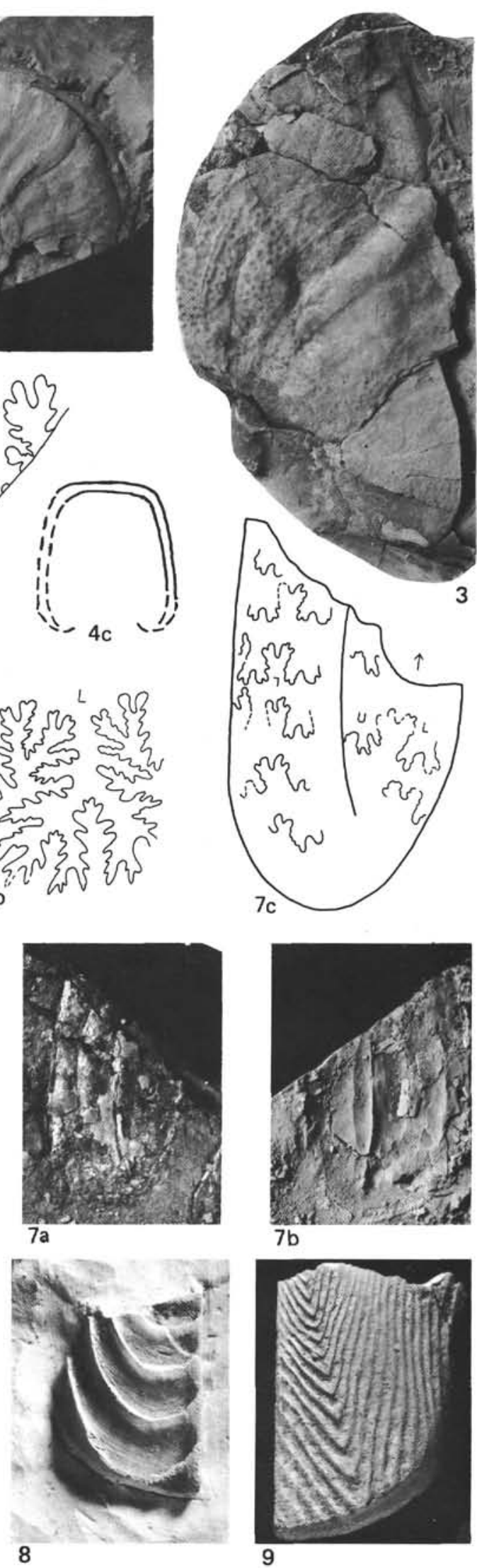